$\begin{array}{lllllll}\text { 井上 純一。 } & \text { 中川 } & \text { 暃壮 } & \text { 中西 } & \text { 信輔 } & \text { 野村 } & \text { 正博 } \\ \text { 網岡 } \text { 逸男 } & \text { 柴田 } & \text { 醇 } & \text { 前田 } & \text { 種雄 } & \text { 赤木 } & \text { 笑入 }\end{array}$

\title{
A CASE OF HEPATOMA WITH INTRAVASCULAR TUMOR GROWTH INTO RIGHT ATRIUM
}

Junichi INOUE,MD, Shoso NAKAGAWA,MD, shinsuke NAKANISHI,MD,

Masahiro Nomura,MD, Itsuo Amioka,MD, Jun ShibATA,MD,

Taneo MAEDA, MD and Emiiru AKAGI,MD

Department of Internal Medicine, Hiroshima City Hospital

\begin{abstract}
概要 腹水と下腿浮畽を主訴之し，諸検査に上り生前に肝癌の右心房内発育を診断した症例を 報告する，症例は69才の男性. 昭和55年 9 月前胸部圧迫感があり, 高血王にて通院加療. 12 月 には腹満感があり肝機能巽常を指摘された。昭和 56 年 1 月両下腿浮腫を認め入院。入院時黄疸 なく，腹部膨隆・肝腫大あり，静脈怒張はない，肝機能検查異常， $\gamma$-globulin高値，KICG0.047

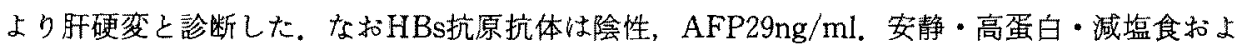
び利尿剂の投与により，腹水・下腿浮腫は消失した。しかし，腹部CTにて肝右葉にlow density area,下大静脈の閉塞, 半奇静脈の搪張をみ, 肝シンチにて右葉にSOLを認めた. 腹腔動脈造影 にて同部にhypervascularity格よび右心房へ至るthread and streaks signをみ, 経右心房下大 静脈造影棌て右心房内に欠損像を認め, 肝癌による二次性Budd-Chiari症候群之診断し, 手術不 能の判断で免废化学療法を開始した，しかし，AFPが上昇し，7月には25000ng/mlを呈した。 腹满感・下腿浮腫・腹壁静脈の怒張がるられ，8月上旬吐血にて死亡した。剖検上肝癌は肝外 血管内発育を示し，下大静脈から右心房起始部束で及んでいた。本邦では二次性Budd-Chiari症 候群の原因として肝癌に上るものが多く，右心房内発育は0.6 4.3\%にすぎない，乙か子剖検 で発見されることが多く，生前に右心房内発育と診断したものは文献上 4 例と数少ない，本例 ではBall valve thrombus syndromeは瘇瘤の連続発育のため認められず, 深部の側副路の発達 により末期をで表在腹壁静脈の怒張は出現しなからた。最近長足の進歩をとげた画像診断によ り，生前に䧐断しえた貴重な症例と考方られた。
\end{abstract}

はじめに

Budd-Chiari症候群はBudd $\left.{ }^{1} お よ ひ ゙ C h i a r i\right)^{22} か ゙$ 肝 静脈閉塞についての病理学的所見明らかにして 以来注目されて扣り, 臨床的に肝脾腫・腹水・浮 腫・腹壁静脈の怒張等の症状を示す比較的希な疾 患である.今日に至る至で本症候群は剖検により 偶然に発見されることが多かつたが，最近の画像

\footnotetext{
[昭和59年 1 月 10 日受稿]

本論文の要旨は第17回日本肝缄学会西部会(名古屋)（昭 和57年11月18日)主題示説:肝内肝外の血管病变にて発表し た。
}

診断や血管造影法の進歩により早期に生前に診断 できるよらになつだけ し). しかし，臨床的に肝癌の 右心房内への血管内連続発育を血管造影法等によ り診断した報告は数少ない、6ー8).

我々は最近腹部CT検查がその端緒となり，肝静 脈・下大静脈内より連続性に右心房内への腫癔発 育を腹腔動脈造影，下大静脈造影にて診断し，剖 検にて確認した興味ある肝癌症例を経験したので 若干の文献的考察を加党て報告する。

\section{症 例}

患者： 佐 ○木○，69才，男性，会社役員. 
主訴：腹部膨満感, 下腿浮腫.

家族歴: 伯母, 直腸癌.

既往歴：36才腸チフス, 54才虫垂炎手術, 酒 ； ビール 1 本/日( 40 年間), タバコ 40 本/日, 常用薬 特になく, 輸血歴なし。

現病歴： 昭和55年 9 月下旬ラジオ体操中めま い, 動悸, 前胸部圧迫感が出現し，数分間で括さ まつたが，その後も体動時に同様の症状があるた め10月上旬近医を受診. 高血压 $(206 / 90 \mathrm{mmHg})$ を指摘され通院加療を行ならす軽快せず，同様の 症状が持続した。12月上旬には全身倦念感が生じ 肝機能異常を指摘され当科を紹介された。自覚的 に腹満感, 易疲労感あり, 食後に上腹部に鈍痛が ある，放散痛はない，以前より時々痋痒感はあつ たが全経過を通じ発熱, 黄㾝, 悪心, 呕吐はない。

入院時現症：意識清明. 身長 $160 \mathrm{~cm}$, 体重 61 $\mathrm{kg}$, 手掌紅斑あるもくも状血管庫，女性化乳房， 白爪, 色素沈着はない. 脈拍66/分, 整, 緊張良好, 血圧 $172 / 100 \mathrm{mmHg}$, 眼瞼・眼球結膜に貧血，黄疸 はなく，心肺打聴診上異常なし、肺肝境界第 6 肋 間. 腹部は全体として膨隆し，腹壁静脈の怒張は ないが腹水詝留あり。肝は脐上 2 横指触知す。辺 縁鈍，硬度硬，表面不平，王痛あり。血管雑音， 摩擦音なし，脾は触知しないが脾濁音界は 5 横指
と拡大。腎触知せず。下肢浮腫著明，腱反射異常 なし。

入院時検查成績(表 1)：末梢血で軽度の貧血 扣よび白血球分類にて好中球増加がみられた，肝 機能検査では膠質反応上昇, GOT, GPTともに軽 度上昇, ChEaseの低下, KICGの著明な低下, 高 $\gamma$ グロブリン血症があり，肝硬変が示唆された。

HBs抗原抗体系は陰性，AFPの上昇はなかつた が，血清補体価CH50は34.9U/ $\mathrm{ml}$ と高值を示し， 悪性疾患が疑われた。胸部X線像では肺門陰影の 㹡大, 横隔膜の挙上はなく心電図には異常所見は 認めなかつた。

腹部CT所見; 肝右葉後下区域にlow density areaを認め,下大静脈は径 $4 \mathrm{~cm}$ と拡張し内部不均 一であつた。 angiografin急速点滴静注にて下大静 脈は全くenhanceされず，拡張した半奇静脈が抽 出さ礼Budd-Chiari症候群が示唆された（図 1).

肝シンチグラム ( ${ }^{99 m}$ Tc-phytate)；入院時 flying bat patternで右葉にuptakeの低下があり， 右側面像にてSOLがみられ。 3 力月後には右葉の uptakeの低下は回復したが，7カ月後には再び uptakeの低下および抬大がみられ, Gaシンチにて 同部に陽性集積像を認めた（図 2 ）。

腹腔鏡検查；脾は肋弓下 1 横指と腫大乙表面

表1. 入院時検査成績

\begin{tabular}{|c|c|c|}
\hline 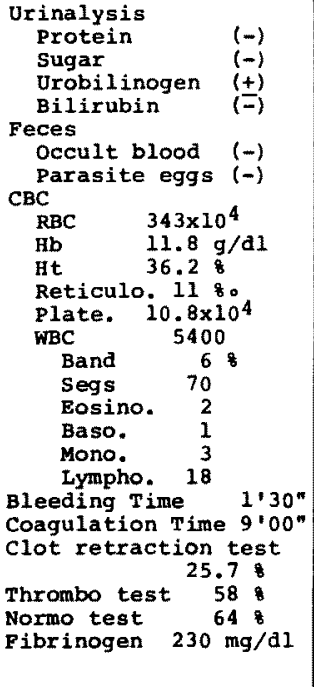 & 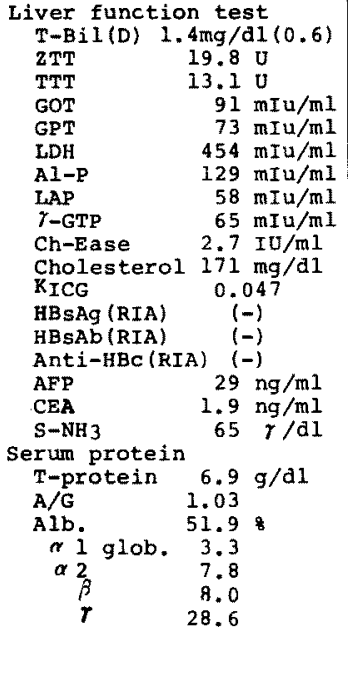 & $\begin{array}{lr}\text { IgG } & 2860 \mathrm{mg} / \mathrm{dl} \\
\text { IgA } & 227 \mathrm{mg} / \mathrm{dl} \\
\text { IgM } & 359 \mathrm{mg} / \mathrm{dl} \\
\text { C3 } & 106 \mathrm{mg} / \mathrm{dl} \\
\text { Blood Chemistry } & \\
\text { BUN } & 16 \mathrm{mg} / \mathrm{dl} \\
\text { Creatinine } & 1.1 \mathrm{mg} / \mathrm{dl} \\
\text { Uric acid } & 7.2 \mathrm{mg} / \mathrm{d} 1 \\
\text { FBS } & 79 \mathrm{mg} / \mathrm{dl} \\
\text { S-Amylase } & 144 \mathrm{so.U} \\
\text { Na } & 142.3 \mathrm{mEq} / 1 \\
\text { R } & 3.8 \mathrm{mEq} / 1 \\
\text { Cl } & 107.4 \mathrm{mEq} / 1 \\
\text { Ca } & 8.4 \mathrm{mg} / \mathrm{d} 1 \\
\text { P } & 2.5 \mathrm{mg} / \mathrm{dl} \\
\text { Cu } & 108 \mathrm{r} / \mathrm{dl} \\
\text { Fe } & 141 \mathrm{Y} / \mathrm{dl} \\
\text { ESR: } 21 \mathrm{~mm} / 1 \mathrm{hr} & 39 \mathrm{~mm} / 2 \mathrm{hr} \\
\text { Imnunological } & \text { examination } \\
\text { CRP } & (-) \\
\text { RA } & (+) \\
\text { Wa-R } & (-) \\
\text { ANF } & (+) \\
\text { S-CH50 } & 34 . \overline{9} \mathrm{U} / \mathrm{ml} \\
\text { PHA test } & 10 \times 12 / 27 \times 30 \mathrm{~mm} \\
\text { PPD test } & 21.5 \times 32 \mathrm{~mm} \\
\text { EEG:WNL } & \end{array}$ \\
\hline
\end{tabular}


に白い線維素の附着がみられた、広範な癒着のた め左葉は裏面しかみえず, 右葉にも一部療着がみ られた。右葉は肋弓直下とやや腫大し褐色調・辺 縁鈍で結節形成があり，腹腔鏡診断は結節肝であ つた。癒着部位には血管の増生・怒張がみられ門

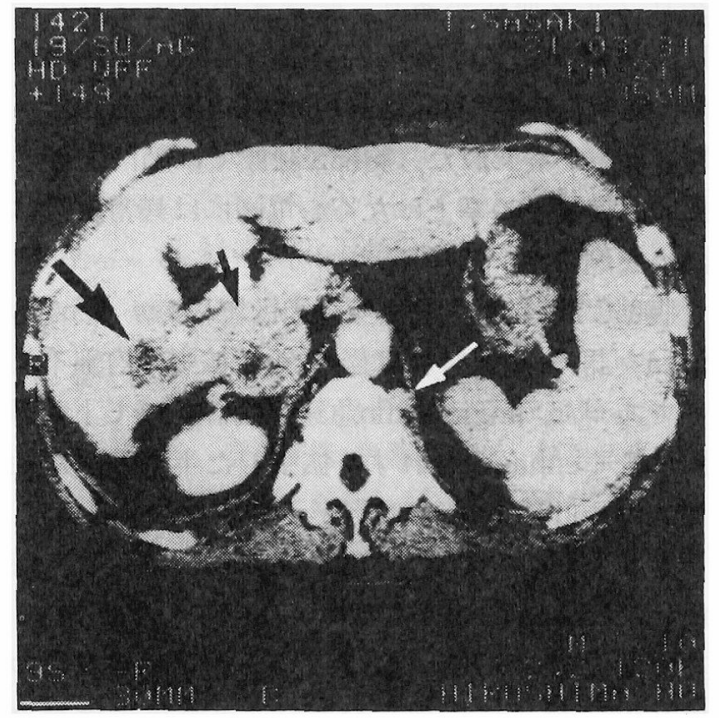

図1. 腹部CT所見. 下大静脈 (黒矢印) は径 $4 \mathrm{~cm}$ と払 張し, angiografinにてenhanceされないが，拡張した 半奇静脈 (白矢印) が抽出された。黑大矢印は肝腫瘍
脈殴六進症が示唆され，リンパ管のうつ滞がみら れたが，線維素沈着・青紫色の区域扣よび腫瘤は 認められず，腹水はみられなかつた（図 $3 \mathrm{~A} ， \mathrm{~B}$ ).

選択的腹腔動脈造影；動脈相にて右葉下部に hypervascularityを認め肝癌と診断した。特徵的 なことは下大静脈内から右心房内まで刷毛状に線 状の血管増生像いわゆるthread and streaks sign が認められ, 腫瘍の右心房内発育が示唆された(図 4).

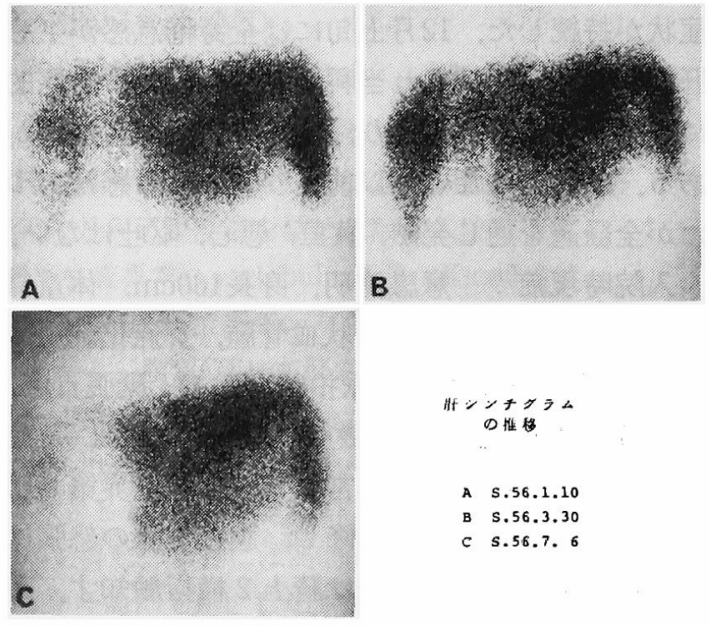

図2、肝シンチグラムの推移

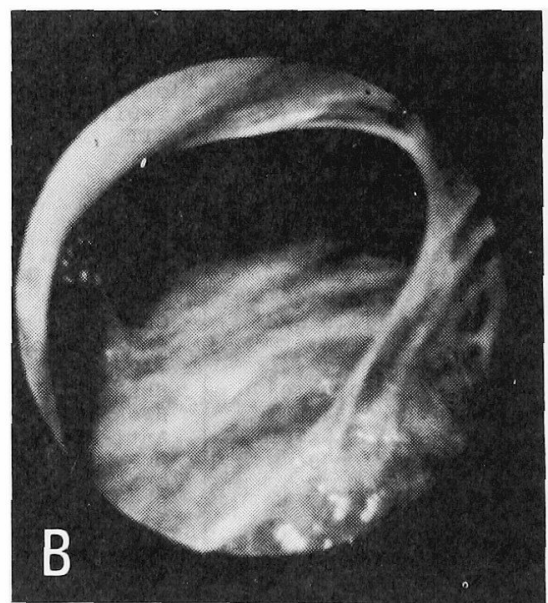

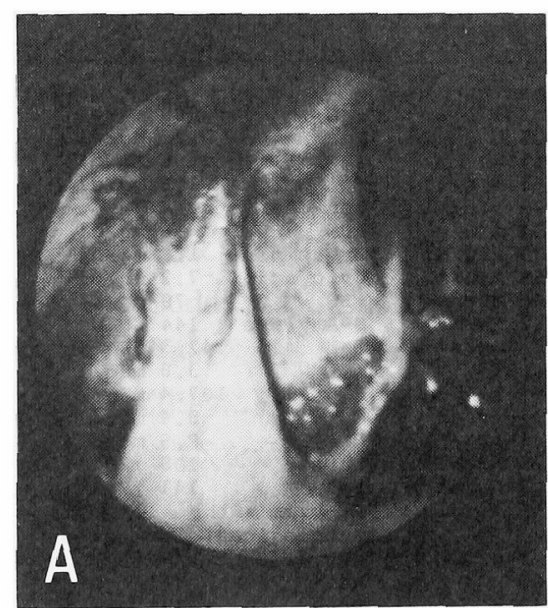

図3、腹腔鏡検查：左葉および右葉の一部にも瘾着あり（A). 右葉は肋弓直下とやゃ 腫大す，辺縁鈍，褐色調，表面には結節形成がありリンパ管のうつ滞あるも線維素沈 着・青紫色の区域・腫瘤はみられない（B）。なお癋着部に血管の增生怒張があり門六 症が示唆された（A). 


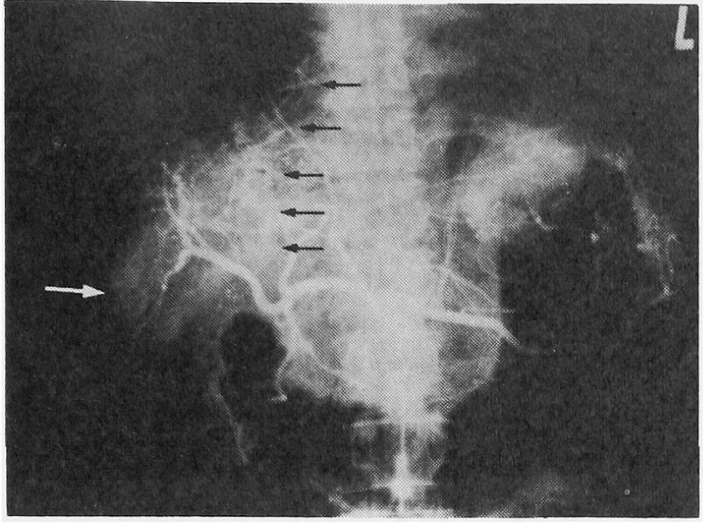

図4. 選択的腹腔動脈造影. 右葉下部にhypervascularity (白矢印) を認めた. 下大静脈内から右心房に至る thread and streaks sigs（黒矢印）がみられ腫場の右 心房内発育が示唆された.

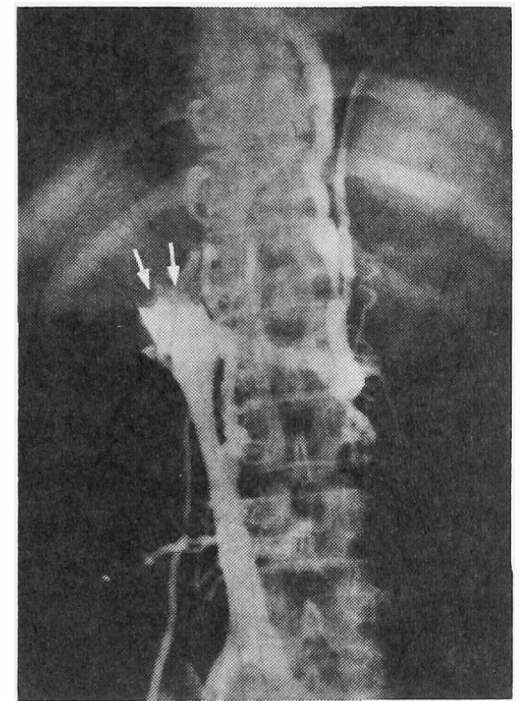

図5. 経大眼静脈一下大静脈造影.下大静脈は腎静脈分 岐部上部にて完全閉塞され閉塞部（白矢印）は凹凸不 整である。

経大眼静脈一下大静脈造影；下大静脈は腎静 脈分岐部上部にて完全閉塞され，閉塞部は凹凸不 整である. 左腎静脈・上行腰静脈・半奇静脈の側 副路がみられるが, 門脈・表在腹壁静脈の拡張は みられない(図 5).

経右心房-下大静脈造影； カテーテルは右肝 静脈にwedgeされ，それ以上の插入はできず右心

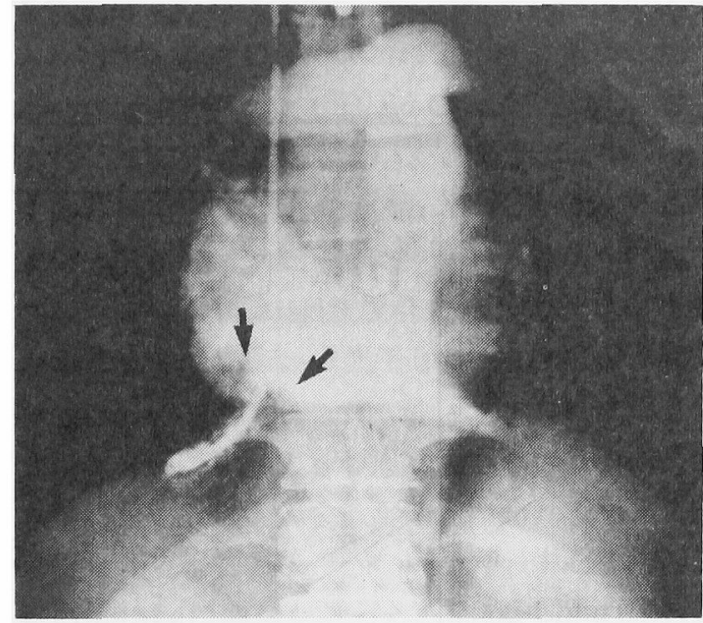

図6. 経右心房一下大静脈造影.カテーテルは右肝静脈 にwedgeされ，それ以上の挿入はできず右心房内に不 整な欠損像（黒矢印）を認めた。

房内に不整な欠損像を認めた（図 6 ).

以上より肝癌の肝静脈・下大静脈から右心房内 への発育による二次性Budd-Chiari症候群と診断 した。

入院後経過 (図 7)：安静, 高蛋白, 減塩食を 与えfurosemide, spinorolactoneの併用により利 尿がおこり，1 週間後には体重が $61 \mathrm{~kg}$ から $57 \mathrm{~kg}$ と減少, 腹水・下腿浮腫も消失乙, 血圧も $120 / 70$ $\mathrm{mmHg}$ と下降した. OK-432+5-Fuによる免疫化 学療法にて治療を開始し，一時発熱をみたがindomethacin Supp.投与により軽快し昭和56年 5 月 1 日退院した。 以後通院加療を行なつたが, 肝 シンチ, 腹部CTにて腫瘤は増大し,さらにAFPも 高値となり 7 月には $25000 \mathrm{ng} / \mathrm{ml}$ 示した。自覚的 に腹満感・全身倦急感があり，下腿浮腫が出現し た. その後 $38 \sim 39^{\circ} \mathrm{C}$ の発熱をみ食欲不振が強くな り 7 月 16 日再入院. 加療により下熱したが, 食欲 不振が増悪し羽だたき振戦出現. III度の意識障害 を伴うようになり, Lactuloseの注腸, 肝疾患特殊 組成アミノ酸液 (THF) , KMの投与により一時意 識状態は改善した。 8 月 9 日よりタール便をきた し, かつ疝痛様の上腹部痛を生じた。翌日黒色泥 状物を多量呕吐し死亡した。

剖検所見： 主要剖検所見は以下の如くであ 


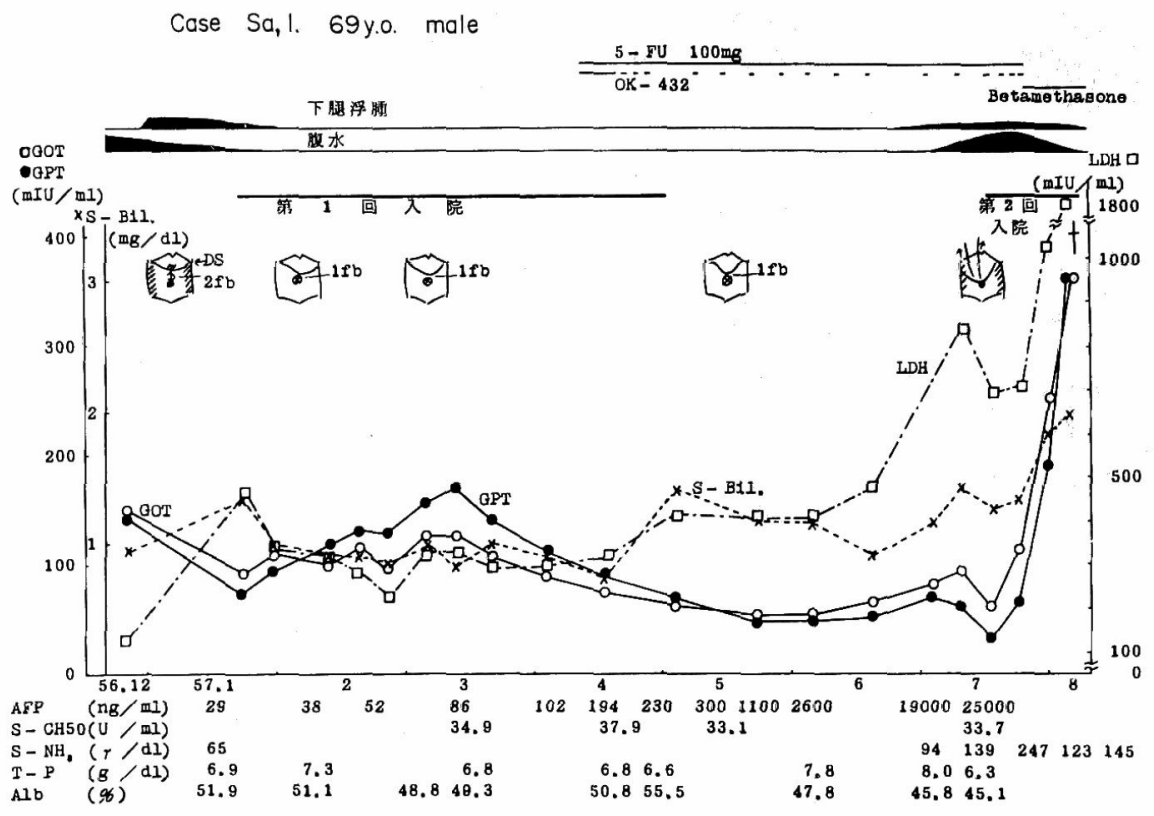

図7. 臨床経過

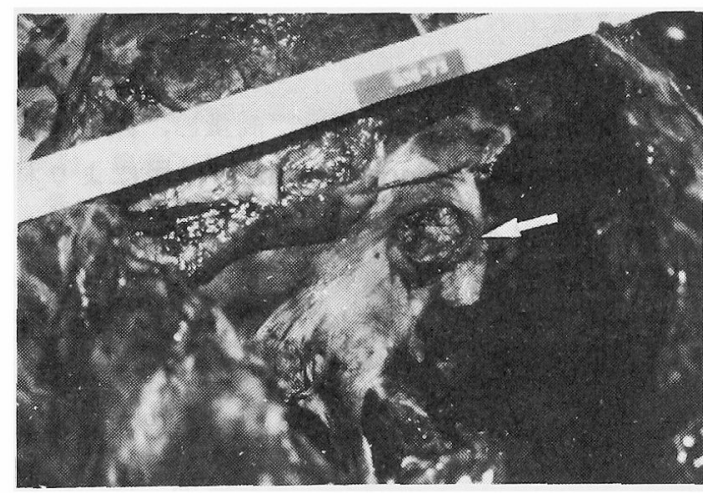

図8，右心房内腔に下大静脈より突出した腫瘤（白矢 印).

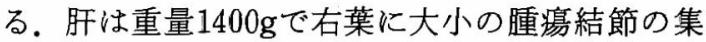
簇からなる $11 \times 10 \times 6 \mathrm{~cm}$ 大の腫瘍塊を認める.腫 瘍の被膜形成は明らかでない。一方，左葉は典形 的な乙型肝硬変の像を認める。肝腫唍は右肝静脈 から下大静脈への血管内発育を示し，その内腔を 完全に閉塞し右心房内腔へも突出している(図 8, 9 ). 腫瘍による下大静脈の完全閉塞のため奇静 脈・半奇静脈は著明に拡張している。組織学的に は肝腫瘍は肝細胞癌 (Edmondson III型)であつた

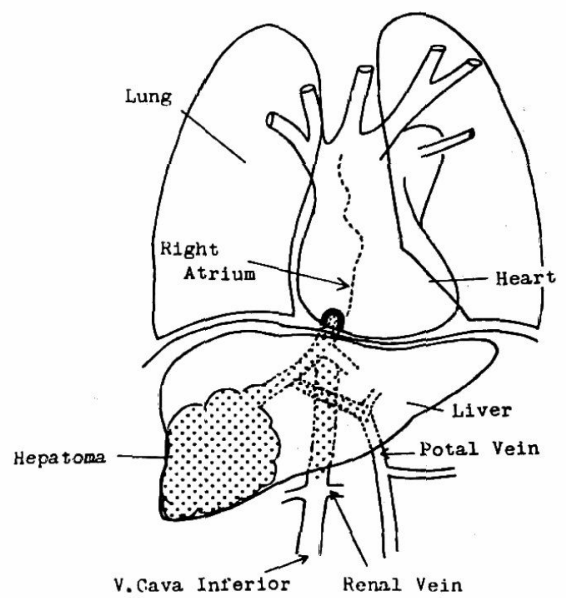

図9. 訮癌分布図

（図10）なお抒，本例では剖検時体腔液の貯留等も 認めていない。腫崵の転移は右副腎に認めるのみ であつた。 その他の所見としては肝硬変に伴ら門 脈硬化症, 慢性うつ血脾, 食道静脈瘤を認め, ま た胃腸管内出血を伴ら急性胃潰瘍を胃角部に認め た。この胃腸管出血が本例の死因とみなされる。

\section{考 案}

Budd-Chiari症候群は1845年Budd ${ }^{1}$ により肝静 


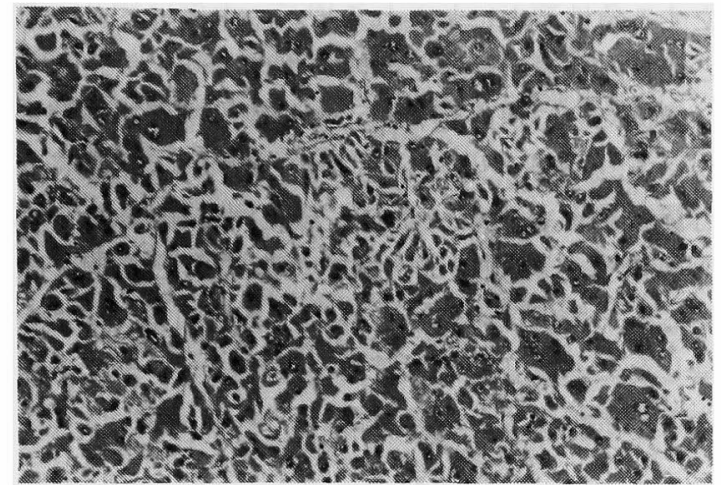

図10. 肝癌組織像 (HE染色, $\times 100)$. 腫复細胞の胞体 および核の大小不同があり胆汁色素の産生はみられな い.一部に多核巨細胞を認めEdmondson III型と診断 した. 静脈うつ滞による乏血のため細胞相互の離解が 強い.

脈閉塞例として記載され, 1899年Chiari ${ }^{2)}$ がその13 例について詳細な報告を行なつて以来多くの報告 がなされている．Parker?"本症を原因不明の idiopathic typeとその他の原因の明らかなsecondary typeの 2 型に分類し，本邦ではsecondary typeの原因として原発性・転移性肝癌, 梅毒, 静 脈の先天異常, 腹膜炎, 肝包虫症, 住血吸虫症, 細網肉腫等の疾患があげられている97. とくに本 邦では外国に比し原発性肝癌によるものが主位を 占めており，これは基礎疾患としての原発性肝癌 の発現頻度が欧米に比し有意に多いためと考兄ら れるが，臨床的にBudd-Chiari症候群と診断され る例が少ないのは, 肝癌そのものに基づく症状と 合併する肝硬変の症状とが重なりあつて診断を困 難にしているためと考えられる。しかし，近年の 画像診断・血管造影法の急速な進歩により, 生前 に診断される例がみられている(3) 5). 本例も腹部 CTにより下大静脈の閉塞および半奇静脈の拡張 を指摘されたのがその端緒であり，臨床症状は肝 腫大, 腹水, 下腿浮腫であり, 安静, 高蛋白, 減 塩食お゙よび利尿剂の投与により腹水, 浮腫は消失 し, 腹痛, 腹壁静脈怒張はなく非代償性肝硬変の それと変わることはなからた。

特殊検查成績について検討すると，腹腔鏡像に ついて瘾着の原因は不明であるが，中等度の脾腫
と瘾着部位での血管増生より門脈圧冗進症が示唆 され結節肝を呈し、リンパのらつ滞は認められた が, 被膜の混濁扣よびBudd-Chiari症候群の発生 前より結節肝が成立していたためかBudd-Chiari 症候群特有の青紫色の区域, 糖衣状の線維素沈 着 ${ }^{10)}$ は認めなかつた. 次に肝シムチグラムの推移 についてBudd-Chiari症候群の特徴的所見は両葉 の末梢域でのuptakeは低下し, 中心三角部領域で のuptakeは正常ないし増加を示す。これは直接下 大静脈への流出路をるつ尾状葉が, 正常の血流量 を維持ないしは肥大するためといわれている(1). 本例も入院当初右葉の uptake低下, 中心三角部領 域の uptakeの増加がみられ, Budd-Chiari症候群 の特徵を示したが, 3 カ月後には右葉のuptakeの 低下は回復し, その 4 カ月後には再びuptakeの低 下执よびその拡大がみられた. Meindok ${ }^{12)}$ は経口 避妊薬服用により特有の肝シンチパターンを呈し たBudd-Chiari症候群の25才の女性患者が mesocaval shuntによりuptakeの低下が回復し, 14 カ月 後には再びSOLの出現をみたとしている. 本例も 何らかの機序により肝静脈の血流の改善がみられ たため, uptakeの回復がみられたものと考光られ た.

腹腔動脈造影にて動脈相でのhypervascularity より右葉下部の肝癌と診断し, 下大静脈から右心 房内までのthread and streaks signにより肝癌の

表2. 肝細胞癌における肝静脈および右心房内発育の 頻度

\begin{tabular}{|c|c|c|c|c|c|}
\hline No. & $\begin{array}{l}\text { 報告 } \\
\text { 年度 }\end{array}$ & 報告者 & 所㾔 & 腫場栓褰部 & 䝺度 \\
\hline $\mathbf{1}$ & 1937 & Gustafson & 62 & $\begin{array}{l}\text { 胿静眼 下大静眽 } \\
\text { 右房 }\end{array}$ & $\begin{array}{r}19(30.6 \%) \\
2(3.2 \%)\end{array}$ \\
\hline 2 & 1954 & Edmondson & 65 & $\begin{array}{l}\text { 門眽 } \\
\text { 肝静脈 } \\
\text { 下大竫脈 } \\
\text { 右房 }\end{array}$ & $\begin{aligned} 22 & (33.8 \%) \\
11 & (16.9 \%) \\
7 & (10.8 \%) \\
1 & (1.5 \%)\end{aligned}$ \\
\hline 3 & 1957 & MaoDonald & 84 & $\begin{array}{l}\text { 訮静脈 } \\
\text { 右房 }\end{array}$ & $\begin{array}{r}40(47.6 \%) \\
3(3.6 \%)\end{array}$ \\
\hline 4 & 1974 & 荒 木 & 482 & $\begin{array}{l}\text { 門脈 } \\
\text { 肝静眽 } \\
\text { 下大静眽 } \\
\text { 右屏 }\end{array}$ & $\begin{array}{r}36(7.5 \%) \\
13(2.7 \%) \\
8(1.7 \%) \\
3(0.6 \%)\end{array}$ \\
\hline 5 & 1975 & 下 川 & 113 & $\begin{array}{l}\text { 門脈 } \\
\text { 肝静脈 }\end{array}$ & $\begin{array}{l}80(70.896) \\
15(13.396)\end{array}$ \\
\hline 6 & 1978 & 德 田 & 233 & 右房 & $10(4.3 \%)$ \\
\hline 7 & 1980 & 長 崎 & 7145 & 右闹 & $48(0.7 \% 6)$ \\
\hline
\end{tabular}


右心房内発育を疑い，下大静脈造影により右心房 肉に不整な欠損像を認め, 肝癌の肝静脈，下大静 脈から右心房内への発育による二次性 BuddChiari症候群と生前に診断したのであるが，肝癌 に怙ける肝静脈・下大静脈内拉よび右心房内発有 頻度は文献的に表 2 に示すよ5にそれぞれ $1.7 \sim 47.6 \% ， 0.6 \sim 4.3 \%$ であり，当院での肝静脈 内発育頻度は 72 例中 5 例 $6.9 \%$, 右心房内人は72例 中 2 例 $2.8 \%$ にすぎなかつた。しかし，いずれす剖 検例であり，生前に肝癌の右心房内発育を診断し

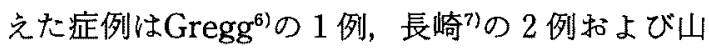
崎8の 1 例と非常に数少ない。とくに長崎》"は右心 房内に発育した肝癌の腹腔動脈造影上の特徵的所 見は，門脈内腫瘍塞栓にみられるthread and streaks signと類似していることを強調してお $り$ ，本例も同所見を認め下大静脈造影にて確定診 断しえた。

下大静脈閉塞時の副血行路についてFerris ${ }^{13}$ は 30 人の患者で 2 日〜 2 年にわたり検討し, 1) central channels, 2) intermediate channels, 3) portal system, 4) superficial routeの 4 型に分類し, central channelsが重要な経路であることを強調 している。本例も下大静脈造影上, 上行腰静脈・ 半奇静脈・奇静脈をとるいわゆる central channels であり，同所見は剖検にても確認できたが，この 㳭部の側副路が十分に発達・形成されていたため, 末期までBudd-Chiari症候群に特長的な表在腹壁 静脈の怒張はみられなかつた。

Hahne ${ }^{14)}$ らは右心房内の球状血栓いわゆる Ball valve thrombus syndromeにより生じる症状とし て，1）発作的な呼吸困難・チアノーゼの出現，2） 発作的に脈拍を触知しにくくなる，3）心雑音の変 化,4）体位変換により呼吸困難の発作が消失する ことをあげているが，本例は末期すで上記症状は みられず，その理由として腫煌が下大静脈から右 心房内まで連続発育し可動性がなかつたためと考 壳られた。

次に臨床経過について数カ月一数年に括よぶ経 過の長い慢性型と悪心, 呕吐, 腹痛, 腹水, 肝腫 大等が急激に抗こり，1〜4週間で肝不全にて死
亡する急性型とにわかれる と比較的緩慢に経過した慢性型であつた。

最後に右心房内発育示方肝癌の病理組織像に ついて, 中島ら ${ }^{16)}$ (肝癌172例の剖検例で 7 例に右 心房内発育を認め，その5ち6 例はI型あるいは IV型を呈し浸潤型が特徵的であつたと強調して いるが，本例は中島らと異なり多結節型のIII型を 呈したことは肝癌の脈管内進展様式が多様である ことを示㖫して和り興味深い。

\section{まとめ}

腹水と下腿浮腫を主訴とし, 安静, 高蛋白, 减 塩食, 利尿剂投与によりそれらは一時改善したが, 画像診断がその診断の契機となり生前に原発性肝 癌による右心房内発育を呈した二次性BuddChiari症候群と診断し，剖検により確認しえた興 味ある症例を経験したので，若干の文献的考察を 加壳て報告した。

謝辞 本症例の病理所見について御教示いただいた当院 病理 松浦博夫博士に深謝致します。

\section{文献}

1) Budd G: On diseases of the liver. London, John Churchill, 1846, pl46.

2) Chiari $\mathrm{H}$ : Über die selbstảndige. Phlebitis obliterans der Hauptstämme der Venaue hepaticae als Todesursache. Beitr path Anat Allg Path $26: 1,1899$.

3) Clain D, et al : Clinical diagnosis of the BuddChiari syndrome. A report of six cases. Amer J Med 43: 544, 1967.

4) Deutch V, et al: Budd-Chiari syndrome. Study of angiographic findings and remarks on etiology. Radiology 116: 430, 1972.

5）止藤隆碩，他：眴部X線所見が診断の端緒となつ たBudd-Chiari莚侯群の 1 症例について. 主とし て血管造影所見に関連して。臨放 $20: 687,1975$.

6) Gregg FP, et al: Arteriographic demonstration of intravenous tumor extension. Amer $\mathrm{J}$ Roentgenol 123: 100, 1975.

7）長崎嘉和，他：腹腔動脈造影及び心ェュー団によ り診断し之た右心房内発育肝紐胞癌の 2 例. 肝臓 $21: 339,1980$.

8）山猗 晃ら：右心室内および大腿静脈に達する広 沉な血管内発育を示した肝細胞癌の 1 例。日消誌 $79: 1478,1982$.

9）高田 昭, 他：Budd-Chiari症候群一主としてsecondary Budd-Chiari淀候群について一. 最新医学 
$24: 1055,1969$.

10）Beck K, 編，市由文弘，稲垣威彦共訳：腹腔鏡力 ラーフトラス, 生体での腹腔葴器の病理解剖学. 南江堂, 東京, 1981，p216。

11) Tavill AS, et al: The Budd-Chiari syndrome: Correlation between hepatic scintigraphy and the clinical radiological, and pathological findings in nineteen cases of hepatic venous out-flow obstruction. Gastroenterology $68: 509$, 1975.

12) Meindok $\mathrm{H}$, et al: Liver scan in Budd-Chiari syndrome. J Nucl Med 17 : 365, 1976.
13) Ferris EJ, et al: The inferior vena cava after ligation and plication: A study of collateral routes. Radiology $89: 1,1967$.

14) Hahne OT, et al: Right atrial thrombi with ballvalve action. Amer J Med 32 : 942, 1962.

15) The Budd-Chiari syndrome. Brit Med J 13: $1302,1979$.

16) Nakashima $T$, et al: Pathological and morphological studies of hepatocellular carcinoma, particularly on metastases and intracanal growth. Kurume Med J 26: 21, 1979. 